\title{
Pseudonannolene canastra sp. nov. (Diplopoda, Spirostreptida) - a new troglobitic millipede from the southwestern state of Minas Gerais, Brazil
}

\author{
Jéssica Scaglione Gallo ${ }^{1,2}$, Maria Elina Bichuette ${ }^{2}$ \\ I Programa de Pós-Graduação em Biologia Comparada, Faculdade de Filosofia Ciências e Letras de Ribeirão \\ Preto, Universidade de São Paulo, Brazil 2 Laboratório de Estudos Subterrâneos, Departamento de Ecologia e \\ Biologia Evolutiva, Universidade Federal de São Carlos, Brazil
}

Corresponding author: Jéssica Scaglione Gallo (jessicasgallo@gmail.com)

Academic editor: O. T. Moldovan | Received 16 February 2020 | Accepted 18 May 2020 | Published 26 June 2020

http://zoobank.org/EDBC1F8F-91B6-4AEE-97BA-60BCA1467D48

Citation: Gallo JS, Bichuette ME (2020) Pseudonannolene canastra sp. nov. (Diplopoda, Spirostreptida) - a new troglobitic millipede from the southwestern state of Minas Gerais, Brazil. Subterranean Biology 35: 33-47. https://doi. org/10.3897/subtbiol.35.51183

\begin{abstract}
Pseudonannolene is a neotropical genus of millipedes distributed in Brazil, Argentina, Paraguay, Uruguay and Bolivia. Generally, species of Pseudonannolene are considered troglophilic, i.e., they can establish a source population in both subterranean and superficial habitats. Among the 60 species known, 49 are found in Brazil; out of these, 25 occur in caves but only three are considered troglobitic (source population exclusively subterranean). This study aims to describe the fourth troglobitic species of Pseudonannolene from Brazil, and the first one from the region of Serra da Canastra, in the southeastern part of Brazil.
\end{abstract}

\section{Keywords}

diplopod, hypogean, neotropical, troglomorphism, Serra da Canastra

\section{Introduction}

Pseudonannolene Silvestri, 1895 (Spirostreptida, Pseudonannolenidae) is a neotropical genus of millipedes distributed in Brazil, Argentina, Paraguay, Uruguay and Bolivia (Schubart 1944; Mauriès 1987; Enghoff et al. 2015). The diagnostic feature of this 
genus is the presence of a longitudinal division of the promentum of the gnathochilarium (Enghoff et al. 2015). Generally, species are considered troglophilic (Trajano et al. 2000; Enghoff et al. 2015), i.e., they can establish a source population in both hypogean (subterranean) and epigean (superficial) environments with individuals that can move between these habitats, thus promoting the flow of selected genes in both environments (Trajano 2012; Trajano and Carvalho 2017).

Among the 60 species known, 49 were reported in Brazil and 25 among these occur in caves, while three are considered troglobitic (Iniesta and Ferreira 2014) i.e., the source population is exclusively subterranean (Trajano and Carvalho 2017). Most of the described species are in the states of Minas Gerais and São Paulo (Gallo and Bichuette 2019). In Brazil, the known troglobitic species include P. spelaea Iniesta \& Ferreira, 2013, from Pará state, P. ambuatinga Iniesta \& Ferreira, 2014, and P. lundi Iniesta $\&$ Ferreira, 2015; these last recorded in the Minas Gerais state. For these species, the troglomorphisms, i.e., modifications in morphological characteristics associated with subterranean isolation (Christiansen 1962), include reduction in body pigmentation, variation in number of ommatidia, body size, and antennae elongation (Iniesta and Ferreira 2015).

Despite little knowledge about this group, two cave species, $P$. ambuatinga and $P$. spelaea, are included in the List of Brazilian Threatened Fauna under Critically Endangered (CR) and Endangered (EN) categories, respectively (Chagas Jr et al. 2018a, b). This classification is based on the IUCN (International Union for Conservation of Nature) rules and adapted to the Brazilian criteria.

This study aims to describe the fourth troglobitic species of Pseudonannolene from Brazil and the first one from the region of Serra da Canastra in southeast Brazil and discuss its troglomorphisms and conservation status.

\section{Materials and methods}

\section{Study area}

The Gruta do Tesouro cave (Figure 1) is located in the municipality of Sáo Roque de Minas, in the region of Serra da Canastra, Minas Gerais state, $350 \mathrm{~km}$ away from the capital Belo Horizonte. The climate of the region, according to Köppen's classification, is Cwa with dry winters and warm summers (Alvares et al. 2013), with rainy season occurring from October to April and dry season from May to September. The vegetation is composed of Cerrado (savanna-like) with riparian and mesophilic forests (Batista et al. 2018).

The Gruta do Tesouro cave is composed of limestone rock belonging to the Bambuí geomorphological unit and has 1,320 m of passageways (Figure 2A). The cave is outside the Serra da Canastra National Park (PNSC) and its surroundings are affected by the pastures adjoining the cave entrance (Figure $2 \mathrm{~B}$ ); uncontrolled tourism is another factor impacting the cave-dwellers. The specimens occur on the riverbank substrate in an aphotic zone, i.e., in complete darkness (Figure 2C) with bat guano piles close by. 

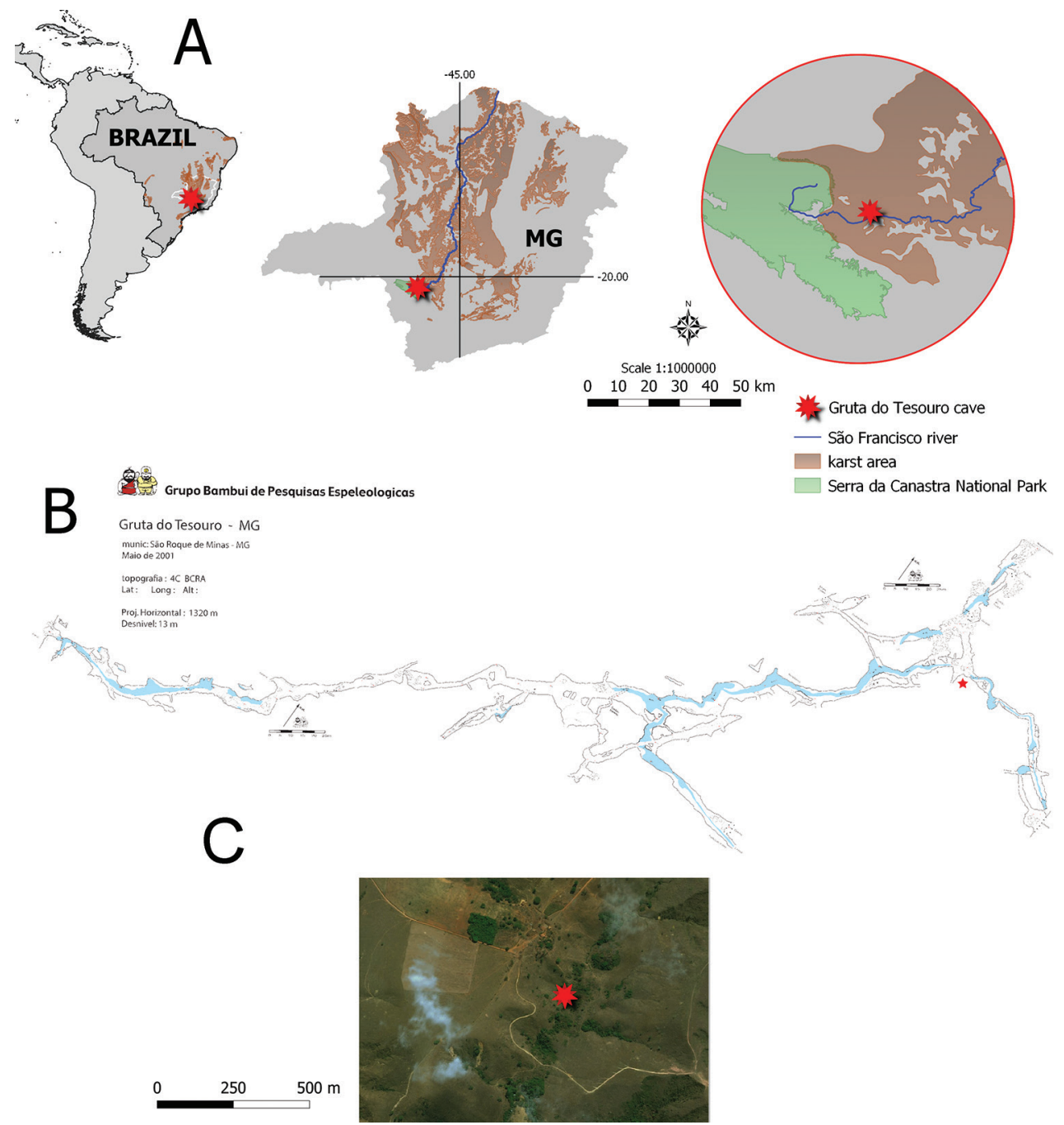

Figure I. Study area A Gruta do Tesouro geographical location (DM von Schimonsky) B cave map; the star corresponds to the entrance used to access the cave in this study (Grupo Bambuí de Pesquisas Espeleológicas) C satellite image; the star shows the entrance of the cave (Bing).

\section{Collections}

The specimens were manually captured by active search and placed in a non-toxic plastic container and taken to the Laboratório de Estudos Subterrâneos at Universidade Federal de São Carlos (LES/UFSCar). The specimens were observed daily for seven days and photographed alive at laboratory. The specimens were then fixed in $70 \%$ ethanol and photographed. The images were captured on a Leica DFC295 camera coupled to a Leica M205C stereomicroscope with Planapo $1.0 \times$ lens and produced by mounting multiple images using the LAS software (Leica Application Suite) V3.7. The holotype was analyzed using a Scanning Electron Microscope (FEI Quanta 250, FEG-SEM) in 


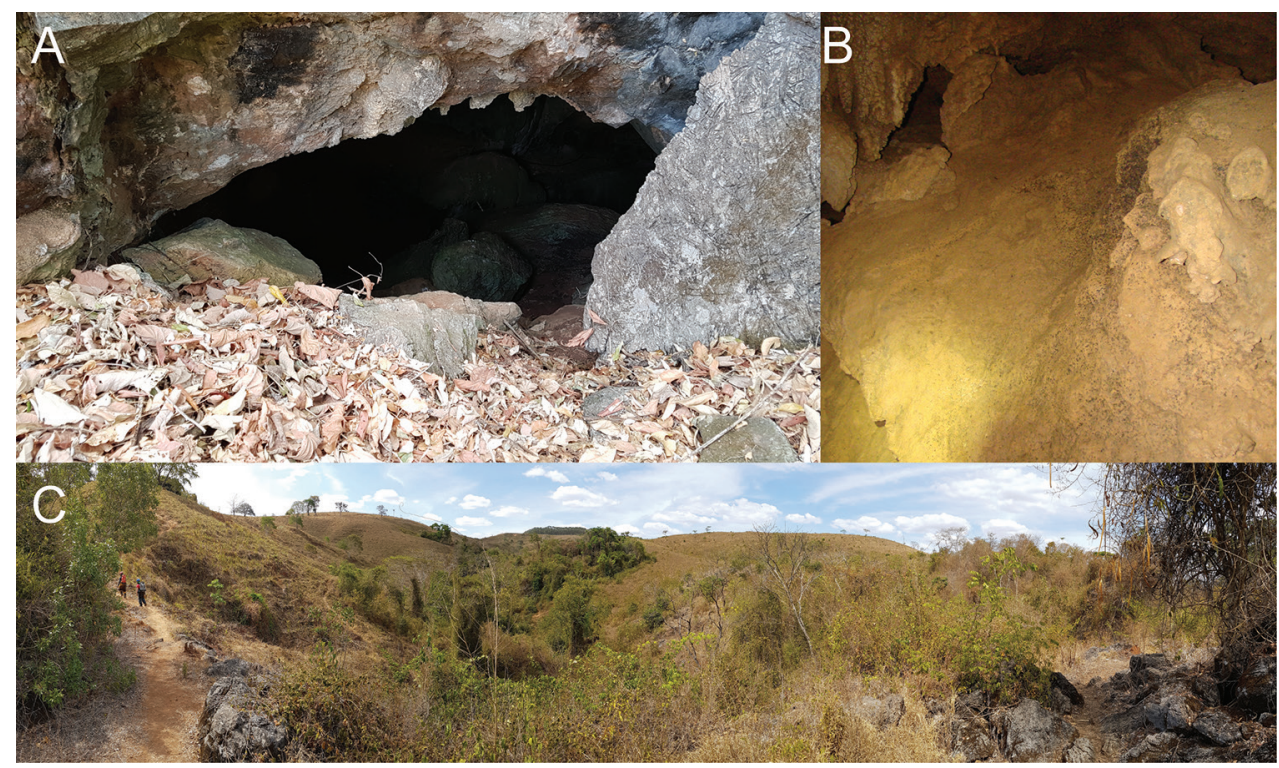

Figure 2. Study Area A principal cave entrance $\mathbf{B}$ riverbank substrate where the specimens were found C landscape view of Gruta do Tesouro cave surroundings. (Photos a and c DM von Schimonsky).

Table I. Species deposited at the Museu de Zoologia da Universidade de Sáo Paulo (MZUSP).

\begin{tabular}{ll}
\hline \multicolumn{1}{c}{ Species } & Collection number \\
\hline P. imbirensis Fontanetti, 1996 & MZUSP1094 \\
P. tocaiensis Fontanetti, 1996 & MZUSP1095 \\
P. halophila Schubart, 1949 & MZUSP1096 \\
P. maritima Schubart, 1949 & MZUSP1098 \\
P. leucomelas Schubart, 1947 & MZUSP1099 \\
P. tricolor Brölemann, 1902 & MZUSP1100 \\
P. chaimowiczi Fontanetti, 1996 & MZUSP1101 \\
P. leucocephalus Schubart, 1944 & MZUSP1102 \\
P. ophiiulus Schubart, 1944 & MZUSP1103 \\
P. silvestris Schubart, 1944 & MZUSP1105 \\
P. urbica Schubart, 1945 & MZUSP1106 \\
P. meridionalis Silvestri, 1902 & MZUSP1115 \\
P. albiventris Schubart, 1952 & MZUSP1116 \\
P. sebastianus Brölemann, 1902 & MZUSP1118 \\
P. paulista Brölemann, 1902 & MZUSP1121 \\
\hline
\end{tabular}

a low-vacuum mode. All individuals that did not present pairs of legs in all segments of the body, that is the growth zone, were considered juveniles (Makarov 2015). The gonopods and the first leg-pair of the male were drawn with the program Adobe Illustrator CC 2014 and the map prepared in the QGIS program version 3.4. The studied material was deposited in the zoological collection at the LES / UFSCar. We examined the species deposited at the Museu de Zoologia da Universidade de Sáo Paulo (MZUSP) (listed in Table 1); besides, the original descriptions of all species of Pseudonannolene (eg. Schubart 1944, 1945, 1947, 1949, 1958, 1960; Silvestri 1895, 1897,1902; Bröle- 
man 1902, 1929; Mauriès 1974, 1987; Fontanetti 1996a, b, 2000; Iniesta and Ferreira 2013a, b, c, 2014, 2015) were used. Thus, we use the terminology used by Schubart $(1944,1945,1947,1949,1958,1960)$ and Fontanetti $(1996 a, b)$ to refer to the components of the diagnostic structures (gonopod and first leg-pair of male).

\section{Results}

\section{Taxonomy}

Order Spirostreptida Brandt, 1833

Family Pseudonannolenidae Silvestri, 1895

Genus Pseudonannolene Silvestri, 1895

\section{Pseudonannolene canastra Gallo \& Bichuette, sp. nov. http://zoobank.org/D1CDA013-785D-4800-A746-87BF93FE48C8}

Figs 3-6

Materials Examined. Holotype: Brazil $\bullet$ đ; Gruta do Tesouro cave, São Roque de Minas, Minas Gerais, Brazil; 26.IX.2017; Fernandes CS, Gallo JS, von Schimonsky DM leg.; LES15282. Paratypes: Brazil • 3 ㅇ (two adults and one juvenile); same locality; 15.VIII.2014; by Bolfarini MP and Zepon T leg.; LES15283 • 1ठ 2 (juveniles); same locality, data and collectors as for holotype; LES15284.

Etymology. The name "canastra" is in allusion to a kind of an ancient chest. This name is also used to refer to the region where the Gruta do Tesouro cave is locate, Serra $\mathrm{da}$ Canastra, that is characterized by a chain of mountais shaped like canastra. Here, we use Canastra as a noun in apposition.

Diagnosis. Pseudonannolene canastra sp. nov. has wide coxa of gonopods resembling those of P. microzoporus Mauriès, 1987, while its solenomerite shape is similar to that of P. maritima Schubart, 1948. However, P. canastra sp. nov. differs from these species in characteristics such as the round shape of the gonopod coxa, the telopodite with a wide base, reduced dentiform processes, different number of spines in the inner part of the coxa (three in the left coxa and four in the right coxa in caudal view), and a divergent pre-femoral process with reduced and flaky pre-femur prolongations. Externally, these species are quite distinct. Pseudonannolene microzoporus, considered troglophilic, has a uniform light brown pigmentation (Mauriès 1987) while P. maritima, recorded only in epigean environment, is brownish or brownish-black, and the head and the first two segments are always lighter, with nearly yellowish color (Schubart 1948).

Holotype description (male). Body length $36.26 \mathrm{~mm}$, ring diameter $1.98 \mathrm{~mm}$, with 59 rings (counting the collum and the telson) (Table 2) without anterior or posterior tapering of the body; the prozonite is shorter $(0.04 \mathrm{~mm})$ than the metazonite $(0.33 \mathrm{~mm})$; metazonite has thin striae in the ventrolateral portion of all the rings; the gnathochilarium is typical of the genus Pseudonannolene with longitudinally divided promentum (Enghoff et al. 2015); head has a posterior suture from the collum to the line of the eyes. 


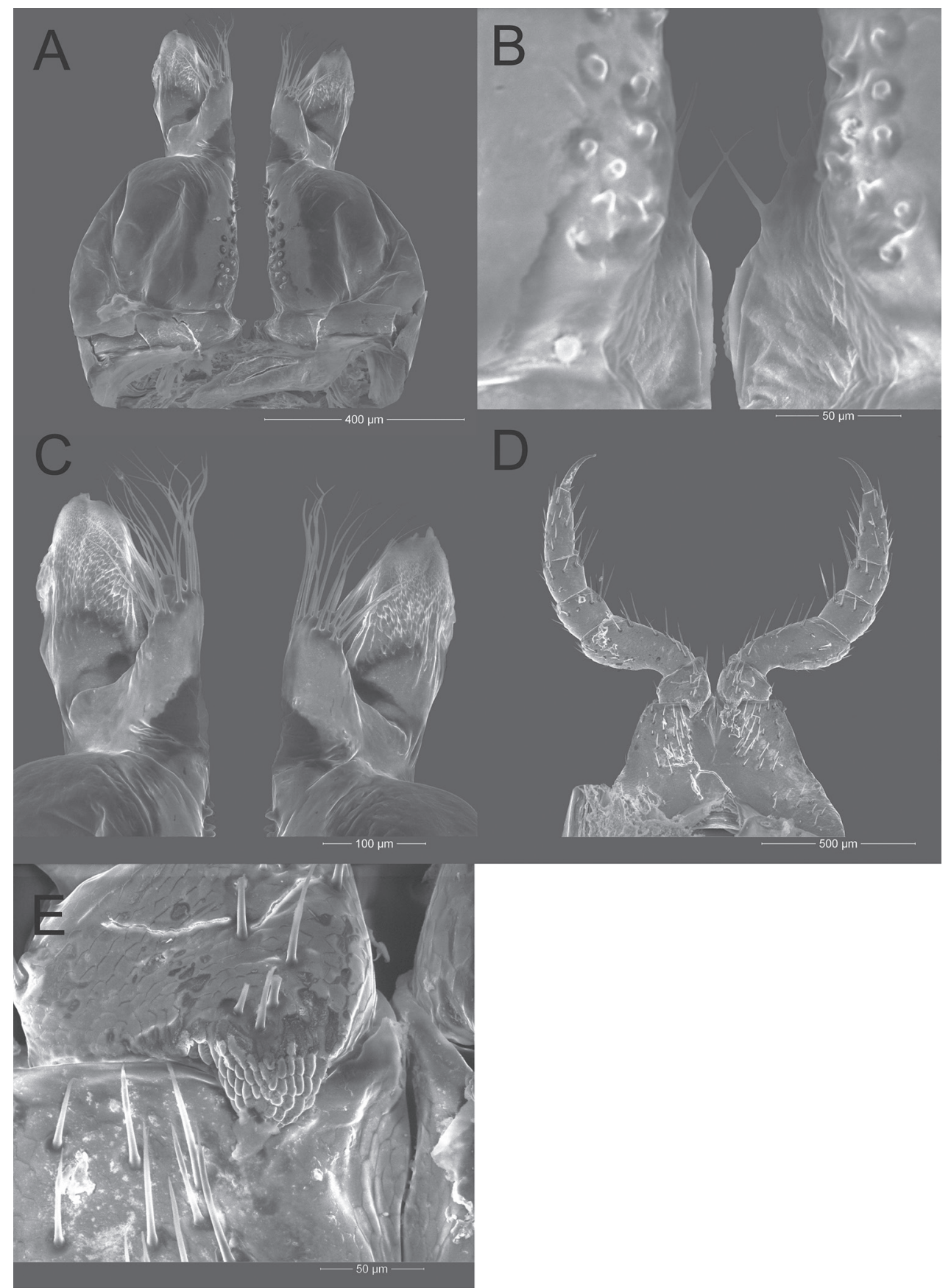

Figure 3. Gonopod an Fist pair of holotype legs by Scannig Electron Microscope (SEM) A caudal view of gonopod $\mathbf{B}$ detail of the internal spines and dentiform process $\mathbf{C}$ detail of solenomerite e telopodite $\mathbf{D}$ caudal view of male first pair of legs $\mathbf{E}$ detail of pre-femural process. Photo: LBR Fernandes. 
Table 2. Morphological data of all the specimens analyzed for description. H: holotype, P: paratype, Ad: Adult, Jv: juvenile, F: female, M: male, R: right, L: left, O: oval, T: triangular, NO: could not be observed.

\begin{tabular}{lcccccccc}
\hline Pseudonannolene canastra sp. nov. & H & P001 & P002 & P003 & P004 & P005 & P006 & P007 \\
\hline Age & $\mathrm{Ad}$ & $\mathrm{Ad}$ & $\mathrm{Ad}$ & $\mathrm{Jv}$ & $\mathrm{Jv}$ & $\mathrm{Jv}$ & $\mathrm{Jv}$ & $\mathrm{Ad}$ \\
Sex & $\mathrm{M}$ & $\mathrm{F}$ & $\mathrm{F}$ & $\mathrm{F}$ & $\mathrm{F}$ & $\mathrm{F}$ & $\mathrm{M}$ & $\mathrm{F}$ \\
Length $(\mathbf{m m})$ & 36.23 & 44.82 & 54.49 & 30.47 & 17.24 & 20.13 & 34.66 & 46.20 \\
$\mathbf{N}^{\circ}$ of rings & 59 & 58 & 67 & $\mathrm{NO}$ & 43 & 46 & 56 & 60 \\
$\mathbf{N}^{\circ}$ of ommatidia & $\mathrm{R}: 22$ & $\mathrm{R}: 20$ & $\mathrm{R}: 24$ & $\mathrm{R}: 22$ & $\mathrm{R}: 8$ & $\mathrm{R}: 11$ & $\mathrm{R}: 19$ & $\mathrm{R}: 18$ \\
& $\mathrm{~L}: 24$ & $\mathrm{~L}: 20$ & $\mathrm{~L}: 28$ & $\mathrm{~L}: 14$ & $\mathrm{~L}: 8$ & $\mathrm{~L}: 11$ & $\mathrm{~L}: 16$ & $\mathrm{~L}: 22$ \\
Shape & $\mathrm{O}$ & $\mathrm{O}$ & $\mathrm{O}$ & $\mathrm{O}$ & $\mathrm{O} / \mathrm{T}$ & $\mathrm{O} / \mathrm{T}$ & $\mathrm{O}$ & $\mathrm{O}$ \\
Anal plate setae & $2+2$ & $\mathrm{NO}$ & $\mathrm{NO}$ & $\mathrm{NO}$ & $2+2$ & $2+2$ & $2+2$ & $2+2$ \\
\hline
\end{tabular}

Pigmentation: In life, the pigmentation of the head, antenna, legs, and body rings is light yellow with no difference in the coloration of the prozonite and metazonite; the ommatidia and ozopores are reddish (Figure 4). Pigmentation in $70 \%$ ethanol: The head, rings, and legs darken after fixation (brown coloration), the eyes become brown like the head by losing the reddish coloration. Only the antenna maintained the original color (Figure 5).

Antenna: Slender ( $2.3 \mathrm{~mm}$ length), covered by fine white setae almost transparent, with some setae larger than others; antennomeres longer than width; the third antennomere is the largest; the sixth antennomere is the widest with a round shape and four sensory cones in the end. The antenna length ratio to the head 1.7 (from the beginning of the suture from labrum) while diameter ratio 1.17.

Eyes: oval-shaped lateral eyes area $0.09 \mathrm{~mm}^{2}$, lengths $0.44 \mathrm{~mm}$ and $0.43 \mathrm{~mm}$ (right and left, respectively); width $0.3 \mathrm{~mm}$; twenty-two ommatidia (Richter et al. 2010) on the right side and 24 ommatidia on the left side (Table 2).

Gonopodium (Figure 6A-D): The coxa is round, $0.45 \mathrm{~mm}$ long and $0.34 \mathrm{~mm}$ wide; the dentiform processes reduced in number and size (Figure $3 \mathrm{~A}$ ) with three internal spines (or processes, Iniesta and Ferreira 2013) on the left side and four on the right side (Figure $3 \mathrm{~B}$, one of the spines is not visible in the figure); the solenomerite end rounded and scaly (Figure 3C) $(0.24 \mathrm{~mm}$ long, $0.12 \mathrm{~mm}$ wide), corresponding to 0.54 and 0.35 of the coxa length and width, respectively; the telopodite smaller than the solenomerite in length $(0.122 \mathrm{~mm})$ but larger in width $(0.139 \mathrm{~mm})$ and corresponds to 0.51 and 1.17 of the solenomerite length and width respectively; it measures $0.15 \mathrm{~mm}$ in length and has a wide base (with thin setae) that narrows gradually (Figure 3D).

First pair of legs (Figure $6 \mathrm{E}-\mathrm{F})$ : coxa longer than wide $(0.58 \mathrm{~mm}$ length, 0.28 $\mathrm{mm}$ width); setae are concentrated in the distal region of the coxa and few setae are found in the proximal region (Figure $6 \mathrm{D}$ ); the coxa base is slightly narrow; the prefemur wider $(0.18 \mathrm{~mm})$ than length $(0.15 \mathrm{~mm})$; strong setae concentrate on the inner side of the pre-femur; pre-femoral process divergent, as small, rounded and scaly extensions in the base of the pre-femur (Figure 3E); femur $(0.27 \mathrm{~mm})$, post-femur 


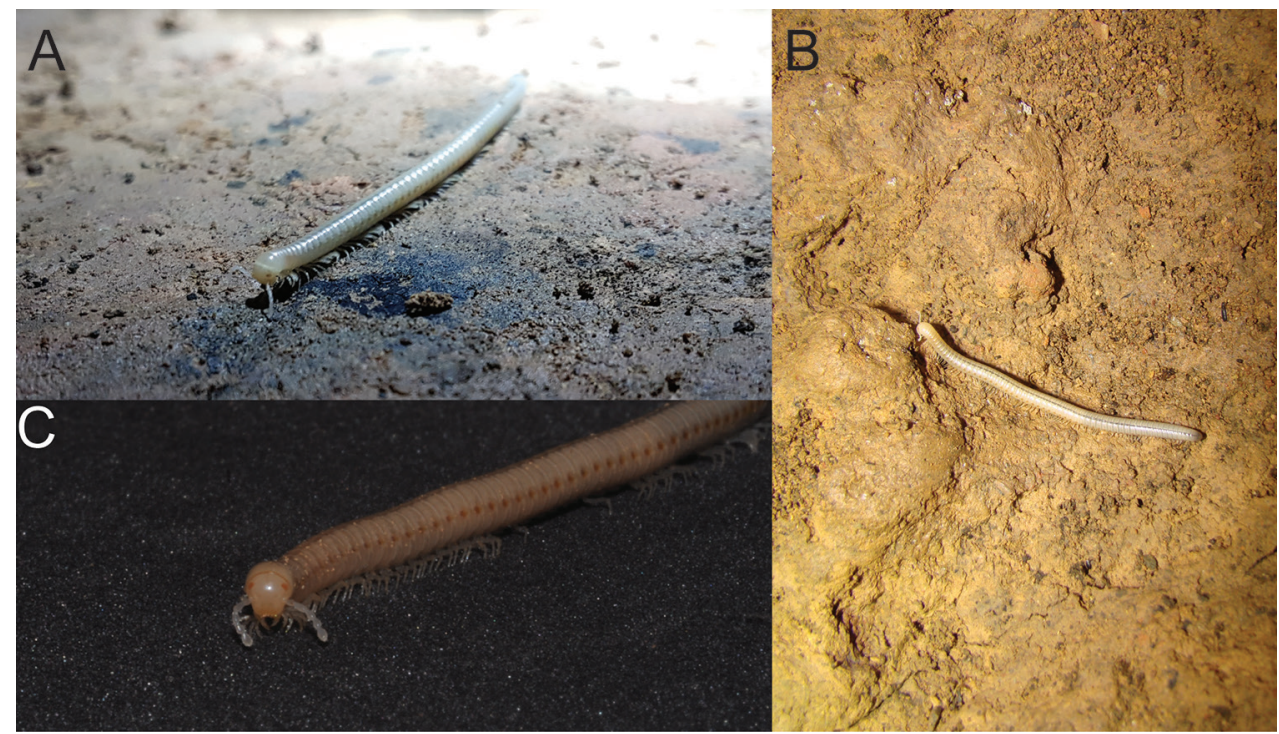

Figure 4. Pseudonannolene canastra sp. nov. live specimens A, B specimens in natural environment $\mathbf{C}$ at laboratory, specimen darkened after contact with artificial light. Photos: A DM von Schimonsky and C DJ Tomaz.

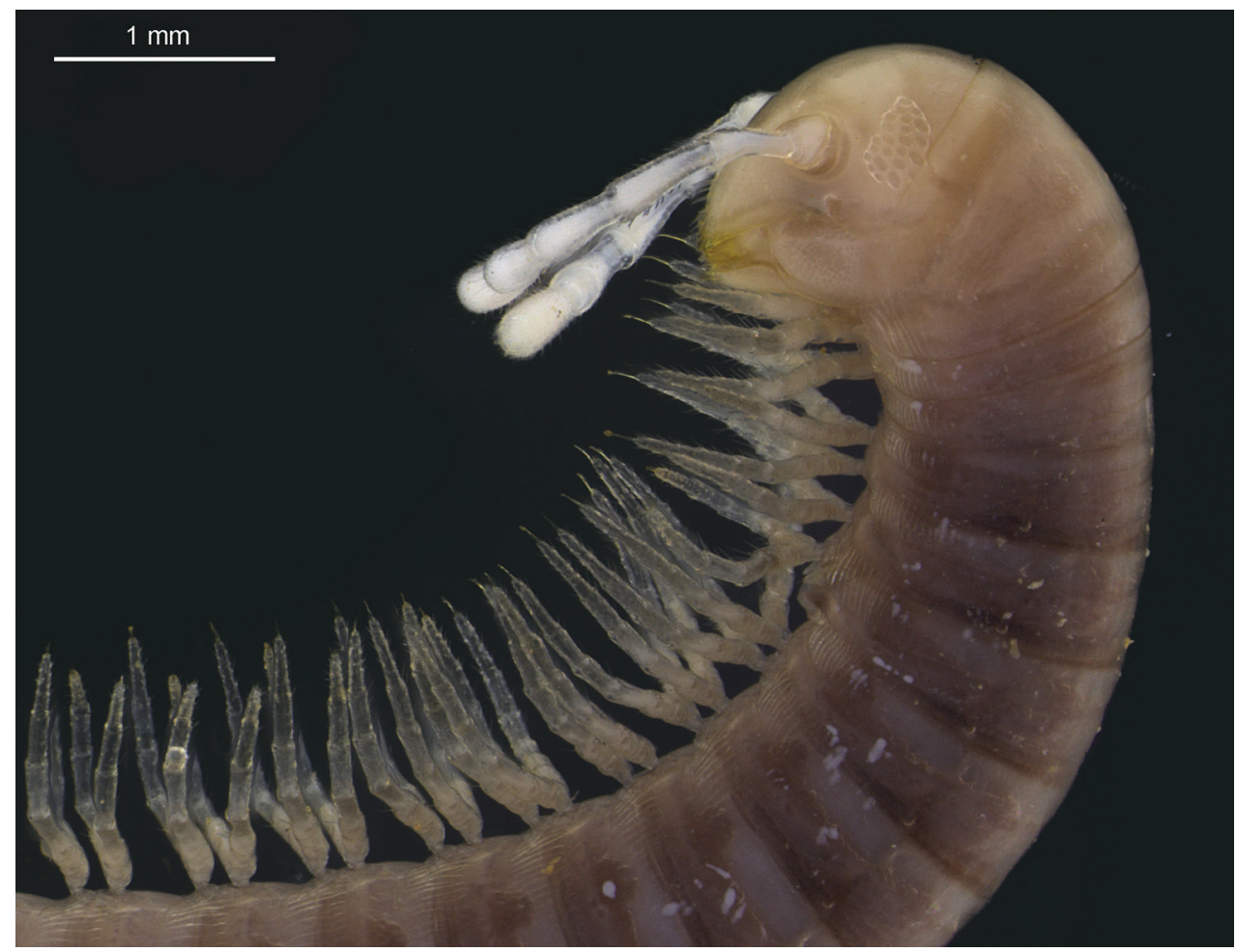

Figure 5. Pseudonannolene canastra sp. nov. in left lateral view, preserved in ethanol $70 \%$. Photo: LBR Fernandes. 

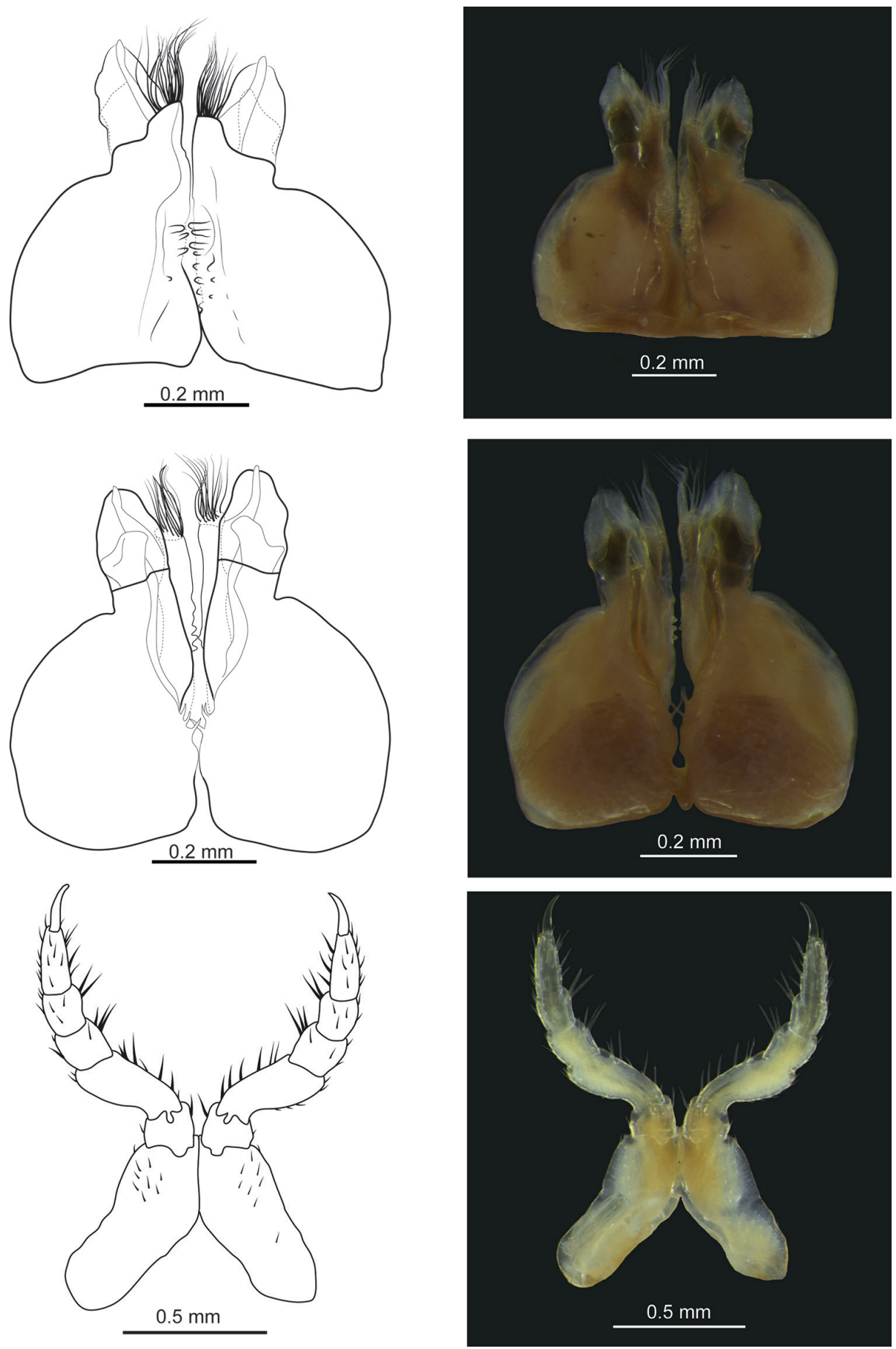

Figure 6. Gonopods and first pair of legs of Pseudonannolene canastra sp. nov. A, B scheme and stereomicroscopic photograph of the gonopods in caudal view $\mathbf{C}, \mathbf{D}$ scheme and photograph in stereomicroscope of the gonopods in oral view $\mathbf{E}, \mathbf{F}$ schematic and stereomicroscopic photograph of the first pair of legs in oral view. Photo: LBR Fernandes. 
$(0.15 \mathrm{~mm})$, tibia $(0.13 \mathrm{~mm})$, and tarsus $(0.22 \mathrm{~mm})$ with thick, elongated setae; the tarsal claw is $0.15 \mathrm{~mm}$ long.

Walking legs (mean values): total length $1.79 \mathrm{~mm}$; coxa $(0.21 \mathrm{~mm})$, pre-femur $(0.26 \mathrm{~mm})$, femur $(0.33 \mathrm{~mm})$, post-femur $(0.27 \mathrm{~mm})$; tibia $(0.23 \mathrm{~mm})$; tarsus $(0.34$ $\mathrm{mm}$ ) with setae on the inner side; all podomeres longer than wide; the tarsal claw 0.14 mm length.

Telson: The anal valve has $2+2$ setae, no sulcus; the pre-anal sclerite does not extend beyond the anal valve; the subanal plate lacks projection (Table 2).

Distribution. An endemic species of Gruta do Tesouro cave, São Roque de Minas, Minas Gerais, Brazil.

Observations. The juveniles, i.e. individuals that did not present pairs of legs in all segments of the body (Makarov 2015), show symmetry in the number of ommatidia; eyes are more triangular than oval. The other characteristics of the body are the same as those of the adults. For this species, the females are larger than the males.

\section{Discussion}

Pseudonannolene canastra sp. nov. is a Spirostreptidan troglobitic millipede restricted to the Gruta do Tesouro cave, with non-occurrence on epigean (surface) habitats, reduction in pigmentation and displaying a classical troglomorphism i.e., the convergence in morphological traits related to isolation in the subterranean environment (Christiansen 1962). Millipedes are a conservative group (Causey 1960) and "pre-adapted" (sensu Arnold 1994) to subterranean habitats. Thus, the inference of morphological modifications associated with the isolation in subterranean environment for the Brazilian Pseudonannolene millipedes is observed to a lesser extent. Only nine troglobitic (i.e. exclusive to the subterranean realm) millipedes have been identified from Brazil: five of them belonging to the order Polydesmida (Dobrodesmus mirabilis Shear, Ferreira \& Iniesta, 2016; Leodesmus yporangae (Schubart, 1946); Phaneromerium cavernicolum Golovatch \& Wytwer, 2004; Peridontosmella alba Schubart, 1957; and Yporangiella stygius Schubart, 1946), three from the order Spirostreptida (P. ambuatinga, P. lundi and P. spelaea), and one from the order Glomeridesmida (Glomeridesmus spelaeus Iniesta \& Wesener, 2012).

Adult millipedes generally have dark pigmentation, while the juveniles can be lighter because of the ecdysis process (Makarov 2015). However, P. canastra sp. nov. maintains light pigmentation in adult stage. The reduction of integument pigmentation was observed in the troglobitic species $P$. ambuatinga, P. lundi, and P. spelaea. Darkening of the pigmentation of $P$. canastra sp. nov. was also observed when they were exposed to artificial lighting. This darkening has already been reported for P. spelaea (Iniesta and Ferreira 2013).

Some cave-dwelling species of the genus Plusioglyphiulus (Spirostreptida, Cambalopsidae) present ommatidia varying from four to 13; this was not considered as a troglomorphic trait (Golovatch et al. 2009). Some examples of troglobitic species belonging 
to the order Spirostreptida are Cambala speobia Chamberlin, 1953; C. reddelli inornatus Causey, 1964; and Mexicambala russelli Causey, 1964; they have been identified from caves in North America. These species show troglomorphic traits such as lack of eyes $(C$. speobia and $M$. russelli) or reduced number of ommatidia ca. 2-7 (C. reddelli inornatus). The species of the Pseudonannolenidae family have four to 45 ommatidia; they are rarely absent (Enghoff et al. 2015). Following this pattern, we do not consider that $P$. canastra sp. nov. has a reduced number of ommatidia. Besides, ommatidia are absent in the pseudonanolenid Typhlonannolene adaptus Chamberlin, 1923, an epigean species, which reinforces the idea that the reduction (until its complete absence) in the number of ommatidia is not simply related to the isolation in the subterranean environment. Therefore, it is difficult to infer if this character-state truly represents a troglomorphism.

There are some gaps in the description of the Pseudonannolene species. One of them is related to the antenna measurements. Forty-one percent of descriptions do not mention the exact measurement or only report that the antenna is long. For the remaining $59 \%$ of the described species, the ratio between the antenna length and the body diameter ranges from 0.59 for $P$. maritima to 1.55 for $P$. tricolor - the last species is considered troglophilic. Considering the troglobitic species - P. spelaea, P. ambuatinga and $P$. lundi, the ratio ranges from 0.86 to 1.04 ( $P$. ambuatinga), 1.03 to 1.08 ( $P$. lundi), and 0.93 to 1.06 (P. spelaea). The antenna length of $2.3 \mathrm{~mm}$ in $P$. canastra sp. nov. is 1.17 of its body diameters, the largest for the troglobitic species. However, this ratio is also large in the troglophilic species $P$. microzoporus (1.27), P. strinatii (1.23 to 1.5 ) and P. tricolor (1.52 to 1.55$)$, for example, even larger than that observed in the troglobitic species.

Considering the body dimensions, the order Spirostreptida ranges from 0.6 to $20 \mathrm{~mm}$ in body diameter (Enghoff et al. 2015). The troglobitic species Cambala reddelli inornatus, M. russelli and C. speobia have a body diameter of $1.0,1.3$, and $1.9 \mathrm{~mm}$, respectively. For the Pseudonannolenidae family, the body is considered slender compared to the other spirostreptidians, with diameters varying from 0.7 to $6 \mathrm{~mm}$ (Enghoff et al. 2015); most of the Pseudonannolene species have a diameter ranging from 2 to $5 \mathrm{~mm}$. The adult $P$. canastra sp. nov. shows a body diameter of $1.97 \mathrm{~mm}$ and is thinner when compared with the other two troglobitic species $P$. ambuatinga (2.4 to $3.36 \mathrm{~mm})$, and P. lundi $(2.4$ to $2.8 \mathrm{~mm})$. However, it is slightly larger than the troglobitic $P$. spelaea $(1.74$ to $1.88 \mathrm{~mm}$ ) in body diameter. Some troglophilic species like $P$. leucocephalus and $P$. taboa show their body diameter ranging from 1.4 to $2.2 \mathrm{~mm}$ and 5.5 to $6.1 \mathrm{~mm}$ respectively. So, we cannot infer whether the body diameter observed in $P$. canastra sp. nov. is a reduction and consequently a troglomorphism or not.

\section{Endemism and conservation}

The Serra da Canastra is known for its scenic beauty with large rocky walls, waterfalls, and its biological richness of fauna and flora (ICMBio 2018). However, the Serra da Canastra National Park (PNSC) is the only protected part of this region. The Gruta 
do Tesouro cave is outside the perimeter of the PNSC and located on private property, therefore, it is unprotected. The farm owners manage tourist activities, and no management plan is implemented.

Pseudonannolene canastra sp. nov. is the first troglobitic species described for Serra da Canastra. The present species is geologically isolated from the other species described for the genus Pseudonannolene due to their occurrence inside the caves. The Municipality of São Roque de Minas is in the geomorphological unit of Bambuí, specifically in the formation of Paraopebas (Karmann and Sanchéz 1979). The nearest described species are from the Pains region located about $85 \mathrm{~km}$ from São Roque de Minas, inserted in the Sete Lagoas formation (another formation of the Bambuí geomorphological unit) (CODEMIG 2003).

Pseudonannolene canastra sp. nov. is mostly found in a specific substrate (the bank of a river) with high humidity; any change in its habitat is dangerous. This species is endemic to the Serra da Canastra region and restricted to the Gruta do Tesouro cave, which is threatened by uncontrolled tourism and deforestation for pasture. Samplings in other caves in the region were made and this species were not found. This can be justified by the limited dispersal power of millipedes (Hopkin and Read 1992; Golovatch and Kime 2009) resulting in a high degree of speciation, and the evolution of many endemic species (Hopkin and Read 1992). The troglobitic species described were found in very moist microhabitats in the caves, associated with drainage or speleothems and, bat guano and vegetable debris as food resources (e.g. Iniesta and Ferreira 2015). Because of these conditions, we carried out a preliminary evaluation concerning the status of conservation of this species following the IUCN (International Union of Conservation of Nature) classification. Pseudonannolene canastra sp. nov. was classified as Critically Endangered (CR) with the criteria B1ab (iii): $\mathbf{B}$ being the restricted geographical area; $\mathbf{B} 1$ the occurrence extension of the taxon $\left(<100 \mathrm{~km}^{2}\right.$ according IUCN, the present species has $51.9 \mathrm{~km}^{2}$ ); $\mathbf{a}$ represents one location and $\mathbf{b}$ (iii) represents the continuous decline of habitat quality. In addition to $P$. canastra sp. nov., two more subterranean species are known from the Serra da Canastra (different taxonomic group) that has been sampled by LES team (Laboratório de Estudos Subterrâneos) since 2009 (Gallão and Bichuette 2018). This shows the potential and biospeleological importance of the region, as well as the need for adequate protection and management of the cave, its surroundings, the watershed and landscape (Galláo and Bichuette 2018).

\section{Acknowledgements}

We thank the ADESITA Project (Agência de Desenvolvimento Econômico e Social de Itabirito $n^{\circ}$ 001-2016 Contrato $\left.n^{\circ} 01-2017\right)$ and Conselho Nacional de Desenvolvimento Científico e Tecnológico (Phd scholarship CNPq process N 140494/20197) for the financial support to JSG; Fundação de Amparo à Pesquisa do Estado de Sáo Paulo (FAPESP, processes 2008/05678-7, 2010/08459-4 and 2016/50381-9 regular project) and Conselho Nacional de Desenvolvimento Científico e Tecnológico (CNPq / productivity fellowship - processes 303715/2011-1, 308557/2014-0 
and 310378/2017-6; regular project - 457413/2014-0) and Coordeação de Aperfeiçoamento de Pessoal de Nível Superior (CAPES, process 88887.159166/2017-00 / project number 440646/2015-4) for financial support to MEB; ICMBio (Instituto Chico Mendes de Conservação à Biodiversidade) for granting the license (28992-7); the Angelica Maria Penteado Martins Dias for the use of the Stereomicroscope and Scannig Electron Microscope (SEM). (INCT Hympar Sudeste - Process FAPESP 2008 / 57949-4 and CNPq 573802 / 2008-4); Luciana B. R. Fernandes for the photos obtained through the stereomicroscope and Scannig Electron Microscope (SEM).; Grupo Bambuí de Pesquisas Espeleológicas (GBPE) for permission to use the cave map; CS Fernandes for help in the field work; MZUSP (R Pinto-da-Rocha and M. Cardoso) for the loan of the type material; DM von Schimonsky for help in the field, preparation of the map and donating the photos; to DJ Tomaz for donating the photos; and CS Fontanetti, CS Fernandes, JE Gallão and T Zepon for their suggestions and help during this study. We would like to thank Editage (www.editage.com) for English language editing. We thank the reviewers William Shear and Ivan Tuf for the careful suggestions made to the manuscript.

\section{References}

Alvares CA, Stape JL, Sentelhas PC, Moraes G, Leonardo J, Sparovek G (2013): Köppen’s climate classification map for Brazil. Meteorologische Zeitschrift 22(6): 711-728. https:// doi.org/10.1127/0941-2948/2013/0507

Arnold EN (1994) Investigating the origins of performance advantage: adaptation, exaptation and lineage effects. In: Eggleton P, Vane-Wright RI (Eds) Phylogenetics and Ecology. Academic Press, 123-168.

Brölemann HW (1902) Myriapodes du Musée de Sao Paulo. Revista do Museu Paulista 5: 35-237. https://doi.org/10.5962/bhl.part.9824

Brölemann HW (1929) Myriapodes recueillis aus Brésil par M. le professeur Caullery, membre de l'institut. Mémoires de la société zoologique de France 29(1): 1-37.

Causey NB (1960) Speciation in North American Cave Millipedes. The American Midland Naturalist 64: 116-122. https://doi.org/10.2307/2422896

Chagas Jr A, Castro-Marcato ACC, Fontanetti CS, Pena-Barbosa JPP, Battirola LD, Bichuette ME, Rodrigues PES (2018a) Pseudonannolene ambuatinga Iniesta and Ferreira, 2013. In: Instituto Chico Mendes de Conservação da Biodiversidade (Org) Livro Vermelho da Fauna Ameaçada de Extinção: Volume II - Invertebrados. Brasília, ICMBio, 461-462.

Chagas Jr A, Castro-Marcato ACC, Fontanetti CS, Pena-Barbosa JPP, Battirola LD, Bichuette ME, Rodrigues PES (2018b) Pseudonannolene spelaea Iniesta and Ferreira, 2013. Instituto Chico Mendes de Conservação da Biodiversidade (Org) Livro Vermelho da Fauna Ameaçada de Extinção: Volume II - Invertebrados. Brasília ICMBio, 467-468.

Christiansen KA (1962) Proposition pour la Classification des Animaux Cavernicoles. Spelunca 2: 76-78.

CODEMIG (2003) Companhia de Desenvolvimento Econômico de Minas Gerais http:// www.codemig.com.br 
Enghoff H, Golovatch SI, Short M, Stoev P, Wesener T (2015) Diplopoda: Taxonomic overview. In: Minelli A (Ed.) The Myriapoda (Vol. 2). Brill, 363-453. https://doi. org/10.1163/9789004188273

Fontanetti CS (1996a) Description of three cave diplopods of Pseudonannolene Silvestri (Diplopoda, Pseudonannolenida, Pseudonannolenidae). Revista Brasileira de Zoologia 13(2): 427-433. https://doi.org/10.1590/S0101-81751996000200013

Fontanetti CS (1996b) Description of a new species and the karyotype of the cavernicolous millipede Pseudonannolene Silvestri and the karyotype of Pseudonannolene strinatti Mauries (Diplopoda, Pseudonannolenida, Pseudonannolenidae). Revista Brasileira de Zoologia 13(2): 419-426. https://doi.org/10.1590/S0101-81751996000200012

Fontanetti CS (2000) Description and chromosome number of a species of Pseudonannolene Silvestri (Arthropoda, Diplopoda, Pseudonannolenidae). Revista Brasileira de Zoologia 17(1): 187-191. https://doi.org/10.1590/S0101-81752000000100014

Fontanetti CS (2002) Taxonomic Importance of the Prefemoral Process of the first Pair of Legs in Males of the Genus Pseudonannolene (Diplopoda, Siprostreptida). Folia Biologica Krakow 50: 199-202.

Gallão JE, Bichuette ME (2018) Brazilian obligatory subterranean fauna and threats to the hypogean environment. ZooKeys 746: 1-23. https://doi.org/10.3897/zookeys.746.15140 Gallo JS, Bichuette ME (2019) What did change in the distribution of the Pseudonannolene Silvestri, 1895 millipedes in Brazilian caves 18 years after the synopsis of Trajano et al. (2000)? Espeleo-Tema. 29(1): 41-55. https://doi.org/10.3897/aca.1.e30225

Golovatch SI, Geoffroy JJ, Mauriès JP, Spiegel DVD (2009) Review of the millipede genus Plusioglyphiulus Silvestri, 1923, with descriptions of new species from Southeast Asia (Diplopoda, Spirostreptida, Cambalopsidae). Zoosystema 31(1): 71-116. https://doi. org/10.5252/z2009n1a5

Golovatch SI, Kime RD (2009) Millipede (Diplopoda) distributions: a review. Soil Organisms 81: 565-597.

Hopkin SP, Read HJ (1992) The Biology of Millipedes. Oxford University Press, New York, 233pp.

ICMBio (2018) Instituto Chico Mendes de Conservação da Biodiversidade. http://www.icmbio.gov.br/portal/visitacao1/unidades-abertas-a-visitacao/198-parque-nacional-da-serrada-canastra

Iniesta LFM, Ferreira, RL (2013a) The first troglobitic Pseudonannolene from Brazilian iron ore caves (Spirostreptida: Pseudonannolenidae). Zootaxa 3669(1): 085-095. https://doi. org/10.11646/zootaxa.3669.1.9

Iniesta LFM, Ferreira RL (2013b) Two new species of Pseudonannolene Silvestri, 1895 from Brazilian iron ore caves (Spirostreptida: Pseudonannolenidae). Zootaxa 3716(1): 75-80. https://doi.org/10.11646/zootaxa.3716.1.6

Iniesta LFM, Ferreira RL (2013c) Two new species of Pseudonannolene Silvestri, 1895 from Brazilian limestone caves (Spirostreptida: Pseudonannolenidae): synotopy of a troglophilic and a troglobiotic species. Zootaxa 3702(4): 357-369. https://doi.org/10.11646/zootaxa.3702.4.3

Iniesta LFM, Ferreira RL (2014) New Species of Pseudonannolene Silvestri, 1895 from Brazilian Limestone Caves with Comments on the Potential Distribution of the Genus in South America (Spirostreptida, Pseudonannolenidae). Zootaxa 3846: 361-397. https:// doi.org/10.11646/zootaxa.3846.3.3 
Iniesta LFM, Ferreira RL (2015) Pseudonannolene lundi n. sp., a new troglobitic millipede from a Brazilian limestone cave (Spirostreptida: Pseudonannolenidae). Zootaxa 3949(1): 123-128. https://doi.org/10.11646/zootaxa.3949.1.6

Karmann I, Sánchez LE (1979) Distribruição das Rochas Carbonáticas e Províncias Espeleológicas do Brasil. Espeleo-tema 13: 105-168.

Makarov SE (2015) Diplopoda-integument. In: Minelli A (Ed.) The Myriapoda (Vol. 2). Brill, 69-99. https://doi.org/10.1163/9789004188273

Mauriès JP (1974) Un cambalide cavernicole du Brésil, Pseudonannolene strinatii n. sp. Revue suisse de zoologie 81(2): 545-550. https://doi.org/10.5962/bhl.part.146025

Mauriès JP (1987) Cambalides nouveaux et peu connus d'Asie, d'Amérique et d'Océanie. II. Pseudonannolenidae, Choctellidae (Myriapoda, Diplopoda). Bulletin du Muséum national d'histoire naturelle 9: 169-199.

Richter S, Loesel R, Purschke G, Schmidt-Rhaesa A, Scholtz G, Stach T, Vogt L, Wanninger A, Brenneis G, Döring C, Faller S, Fritsch M, Grobe P, Heuer CM, Kaul S, Møller SO, Müller CHG, Rieger V, Rothe BH, Stegner MEJ, Harzsch S (2010) Invertebrate neurophylogeny: suggested terms and definitions for a neuroanatomical glossary. Frontiers in Zoology 7: 1-29. https://doi.org/10.1186/1742-9994-7-29

Schubart O (1944) Os Diplópodos de Pirassununga. Acta zoologica Lilloana 2: 321- 440.

Schubart O (1945) Diplópodos de Monte Alegre (Município de Amparo, Est. de São Paulo). Papéis avulsos do Departamento de zoologia São Paulo 6: 283-320.

Schubart O (1947) Os diplopoda da viagem do naturalista Antenor Leitão de carvalho aos rios Araguaia e Amazonas em 1939 e 1940. Museu Nacional.

Schubart O (1949) Os Diplopoda de algumas ilhas do litoral Paulista. Memórias do Instituto Butantan 21: 203-254.

Schubart O (1958) Sôbre alguns Diplopoda de Mato Grosso e Goiás Brasil e a Família Spirostreptidae. Arquivos do Museu Nacional. Rio de Janeiro 46: 203-252.

Silvestri F (1895) Viaggio del dottor Alfredo Borelli nella Repubblica Argentina e nel Paraguay. XIV. Chilopodi e Diplopodi. Bollettino del musei di zoologia e di anatomia comparata della Reale Università di Torino 10(203): 1-12. https://doi.org/10.5962/bhl.part.8048

Silvestri F (1897) Neue Diplopoden. Abhandlungen und Berichte des Königl. Zoologischen und Anthropologisch-Ethnographischen Museums zu Dresden. Dresden 6(9): 1-23.

Silvestri F (1902) Viaggio del Dr. A. Borelli nel Matto Grosso. VII. Diplopodi. Bollettino del musei di zoologia e di anatomia comparata della Reale Università di Torino 17(432): 1-25. https://doi.org/10.5962/bhl.part.26628

Trajano E (2012) Ecological classification of subterranean organisms. In: White WB, Culver DC (Eds) Encyclopedia of Caves, $2^{\circ}$ ed. Academic Press, Oxford, 275-277. https://doi. org/10.1016/B978-0-12-383832-2.00035-9

Trajano E, Carvalho MR (2017) Towards a biologically meaningful classification of subterranean organisms: a critical analysis of the Schiner-Racovitza system from a historical perspective, difficulties of its application and implications for conservation. Subterranean Biology 22: 1-26. https://doi.org/10.3897/subtbiol.22.9759

Trajano E, Golovatch SI, Geoffroy JJ, Pinto-Da-Rocha R, Fontanetti CS (2000) Synopsis of Brazilian Cave-Dwelling Millipedes (Diplopoda). Papéis Avulsos de Zoologia 41(18): 259-287. 